\title{
Distribution and Quantification of Lymphocytes in the Major Lymphoid Organs of Naturally Gumboro Infected Broilers
}

\author{
Distribución y Cuantificación de Linfocitos en los Órganos Linfoides Principales de Pollos de \\ Engorda Infectados Naturalmente con Gumboro
}

${ }^{*, * *}$ Mohammad Mejbah Uddin; ${ }^{* * *}$ Mohammad Saiful Islam; ${ }^{* * * *}$ Joyita Basu \& ${ }^{* * * * *}$ Md. Zahirul Islam Khan

UDDIN, M. M.; ISLAM, M. S.; BASU, J. \& KHAN, M. Z. I. Distribution and quantification of lymphocytes in the major lymphoid organs of naturally gumboro infected broilers. Int. J. Morphol., 30(4):1585-1589, 2012.

SUMMARY: Gumboro disease is caused by the infectious bursal disease virus (IBDV) which rapidly destroys immature Blymphocytes of bursa of Fabricious, and causes immune suppression and high mortality in commercial broiler farms in Bangladesh. To investigate the possible effect of IBDV on lymphocytes and its distribution in the major lymphoid organs, bursa of Fabricious including spleen and thymus of naturally Gumboro-infected broilers, a research was conducted in the Department of Anatomy and Histology, collaboration with the Department of Pathology, Bangladesh Agricultural University, Bangladesh. Bursa of Fabricious, spleen and thymus of 21-days-old Gumboro-infected and non-infected broilers of same age (control) were routinely processed and stained by hematoxylin and eosin to examine the distribution of lymphocytes in the major lymphatic organs as well as quantified the number of lymphocytes under high power magnification field and compared with those of control. The number of lymphocytes in bursa of Fabricious, spleen and thymus of Gumboro-infected broilers were $27.20 \pm 1.53,66.50 \pm 2.70$ and $79.30 \pm 3.92$ whereas $121 \pm 3.82,89.90 \pm 2.09$ and $106.30 \pm$ 4.07 were in non-infected control respectively. The numbers of lymphocytes were significantly $(p<0.05)$ lower in all lymphatic organs of Gumboro-infected broilers than those of non-infected control. The significant numbers of lymphocytes decrease in spleen and thymus suggest that IBVD not only destroy lymphocytes in bursa of Fabricious, but also in spleen and thymus and thus may severely suppress the immune response of IBVD affected broilers.

KEY WORDS: Lymphocyte; Gumboro; Lymphoid organs; Broiler.

\section{INTRODUCTION}

Gumboro/infectious bursal disease (IBD) caused by an avian lymphotropic, infectious bursal disease virus (IBDV) that rapidly destroys immature B-lymphocytes in the bursa of Fabricius and causes immune suppression in chicken (Chen at el., 2009). This immune suppression prevents the birds from optimally responding to vaccine (Sharma et al., 1984) and ultimately leads to increase the incidence of numerous concurrent bacterial (Wyeth, 1975), viral (Giambrone et al., 1977), protozoal (Anderson et al., 1977) as well as fungal (Chowdhury et al., 1996) infections.

IBDV at first replicate into lymphocytes and macrophages in the mucosa associated lymphoid tissues of the duodenum, jejunum and caeca and subsequently replicate in the immature B-lymphocytes of bursa of Fabricius and to lesser degree in other lymphoid organs such as spleen (Rautenschlein, 2001), thymus (Tanimura et al., 1994).

The histopathological changes and immunosuppressive effect on different lymphatic tissues of IBDV infected chicken had been studied in bursa of Fabricius (Elankumaran et al., 2001), spleen (Hoque et al., 2001), thymus (Okoye \& Uzoukwu, 2001), cecal tonsils (Elankumaran et al.) and other non lymphoid organs like liver (Islam et al., 1997). Moreover, the distributions of immune competent cells of major lymphoid organs in

\footnotetext{
Associate Professor, Department of Anatomy and Histology, Faculty of Veterinary Medicine, Chittagong Veterinary and Animal Sciences University, Khulshi, Bangladesh.

** Doctoral Student, Laboratory of Clinical Pathology, Department of Veterinary Clinical Sciences, Faculty of Agriculture, Kagoshima University, Kagoshima, Japan.

*** Assistant Professor, Department of Anatomy, Histology and Physiology, Faculty of Animal Science and Veterinary Medicine, Sher-e-Bangla Agricultural University, Dhaka, Bangladesh.

***** MS Student, Department of Pathology, Faculty of Veterinary Science, Bangladesh Agricultural University, Mymensingh, Bangladesh.

****** Professor, Department of Anatomy and Histology, Faculty of Veterinary Science, Bangladesh Agricultural University, Mymensingh, Bangladesh.
} 
different ages of the infection-free chicken have been reported (Khan et al., 2001). Recently, distribution of lymphocytes in the mucosa associated lymphoid tissues (MALT) of naturally infected IBD chicken has been reported in proventriculus, duodenum, jejunum, ileum, caeca, caecal tonsils and lungs (Uddin et al., 2010). However, relatively little information is available regarding specific effect of this virus on lymphocytes particularly number and distribution in the major lymphoid organs of naturally IBDV infected broilers.

Therefore, the present studies were undertaken to investigate the distribution and quantification of lymphocytes in the major lymphoid organs of the naturally Gumboroinfected broilers. These investigations will provide valuable information and clues for poultry researchers, immunologist, and pathologist to protect broilers from this devastating disease.

\section{MATERIAL AND METHOD}

Sample collection and Tissue preparation. Bursa of Fabricious, thymus and spleen of 21-days-old Gumboroinfected broilers $(n=10)$ were collected immediately after postmortem examination of diseased broilers on the basis of gross lesions at Department of Pathology, Banglaedsh Agricultural University, Mymensingh, Bangladesh. Affected broilers were referred to the university from different commercial poultry farms for diagnostic purpose. After collection, bursa of Fabricious, thymus and spleen of 21days-old Gumboro-infected broilers were fixed in Bouin's fluid (Gridley, 1960) and routinely embedded in paraffin. Sections were cut at $6-\mu \mathrm{m}$-thickness and stained with Harrie's hematoxylin and eosin (H-E) method. The respective organs of non-infected control broiler were collected from apparently healthy chicken of same age $(n=10)$.

Semiquantitative analaysis. The histomorphology of all lymphoid organs of Gumboro-infected and control broilers were studied and the number of lymphocyte were counted in 20 adjacent, non-overlapping fields, using 400x (40x objective, 10x ocular) magnification.
Data analysis. Data obtained from semiquantitative analysis of lymphocytes are presented as means \pm standard deviation (SD). Statistical analysis was performed by ANOVA using SPSS software (version 12, Chicago, USA).

\section{RESULTS AND DISCUSSION}

Bursa of Fabricius. Lymphocytes in the bursa of Fabricius of the Gumboro-infected broilers were $27.20 \pm 1.53$ while $121.00 \pm 3.82$ in non-infected control broilers (Table I). The numbers of lymphocytes were significantly $(p<0.05)$ lower in the bursa of Fabricius of Gumboro-infected broilers than the non-infected broilers. Moreover, severe necrosis, disorganization, depopulation and depletion of lymphocytes were observed in follicles of the bursa of Fabricius in the Gumboro-infected broilers (Fig. 1b). Besides, destruction of lymphocytes was observed in the medullary and cortical area of bursa. Histopathology of bursa of Fabricius observed previously in Gumboroinfected chicken (Rautenschlein et al.). Furthermore, IBDV replicate in the immature B-lymphocytes of bursa of Fabricius as main target cell and might be leads to the destruction of lymphoid cells (Chen et al.).

Spleen. The numbers of lymphocyte in the spleen of Gumboro-infected broilers were $66.50 \pm 2.70$ while $89.90 \pm$ 2.09 in non-infected control broilers (Table I). The lymphocytes were significantly $(p<0.05)$ lower in Gumboro-infected broilers than non-infected control. Lymphatic depletion was observed in both white pulp and red pulp with severe in germinal centers of the lymphatic follicle in the white pulp (Fig. 2b). Moreover, lymphoid cells were greatly reduced in diffuse lymphoid tissue. The results of the present study also suggest that IBDV destroys the lymphocytes significantly in spleen. Although, IBDV positive cells and $\mathrm{T}$ cells suppression has been reported in the spleen after inoculation of virulent IBDV (Rautenschlein et al.).

Thymus. The numbers of lymphocyte in the thymus of Gumboro-infected broilers were $79.30 \pm 3.92$ while 106.30 \pm 4.07 in non-infected broilers (Table I). The lymphocytes

Table I. Quantification of lymphocytes in 21-days-old Gumboro-infected and non-infected control broilers (mean $\pm \mathrm{SD}, \mathrm{n}=10$ ).

\begin{tabular}{ccc}
\hline Lymphatic organs & Gumboro-infected & Control \\
\hline Bursa of Fabricious & $27.20 \pm 1.53^{*}$ & $121 \pm 3.82$ \\
Spleen & $66.50 \pm 2.70^{*}$ & $89.90 \pm 2.09$ \\
Thymus & $79.30 \pm 3.92^{*}$ & $106.30 \pm 4.07$ \\
\hline
\end{tabular}

*Significantly different from control $(P<0.05)$. 


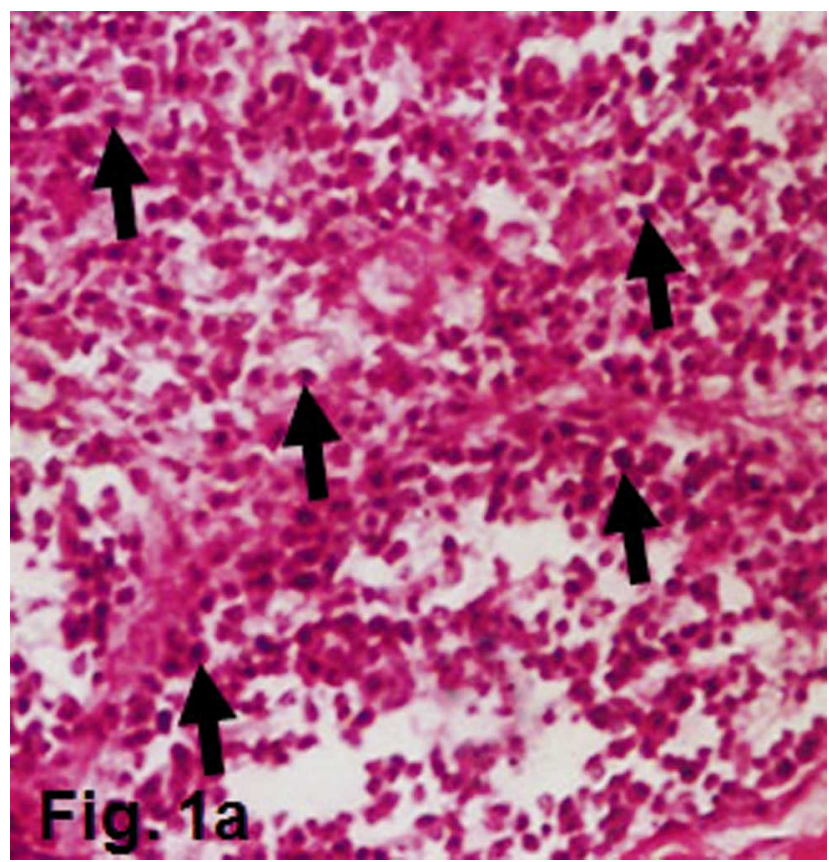

Fig. 1a. Bursa of Fabricious of control broiler showing lymphocytes (arrows) in lymphatic nodules (H\&E, X 400).

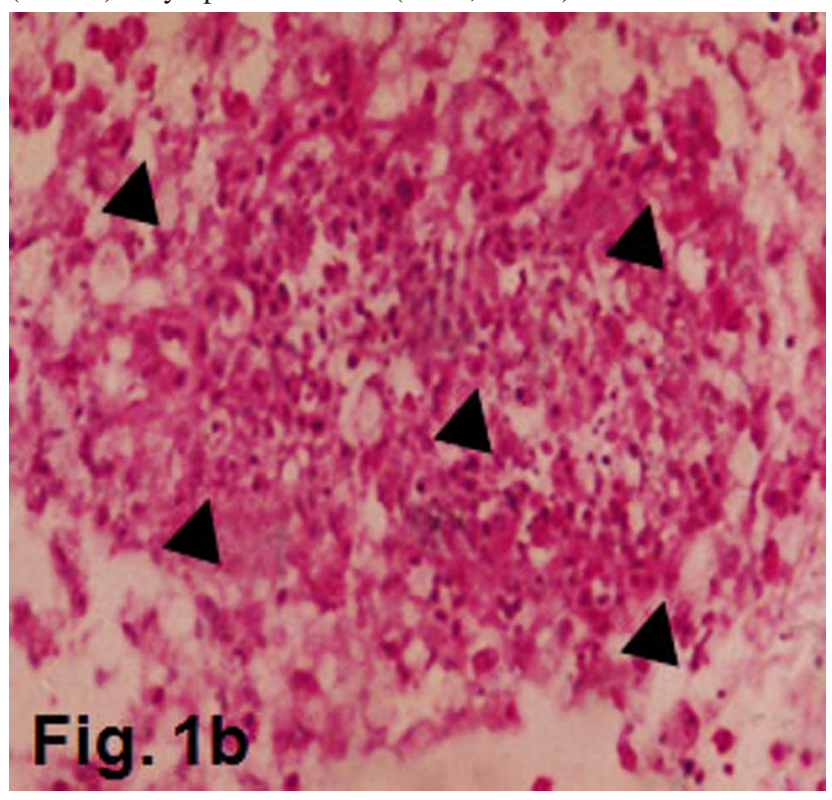

Fig. 1b. Bursa of Fabricious of Gumboro-infected broiler showing lymphocyte depleted areas (arrowhead) in lymphatic nodules $(\mathrm{H}$ \& $\mathrm{E}, \mathrm{X} 400)$.

were significantly $(p<0.05)$ lower in Gumboro-infected broilers than non-infected control. Depletion of lymphocyte was observed in the both thymic cortex and medulla (Fig. $3 b)$. Though, cellular destruction and apoptosis of embryonic thymus has been reported previously following a classical virulent IBDV exposure (Khatri \& Sharma, 2009).
Among the major lymphoid organs, maximum number of lymphocytes was depleted in the bursa of Fabricius than the spleen and thymus of Gumboro-infected broilers. However, lymphocytes of the thymus were affected more severely than that of spleen. The results of the present study clearly demonstrate that IBDV has greater affinity to the lymphocytes of the thymus than the spleen. The virus might be destroyed the $\mathrm{T}$ lymphocytes thuscauses severe immune suppression by destroying both B lymphocytes of bursa of Fabricius and T lymphocytes of thymus and finally failure to optimal response of vaccine.

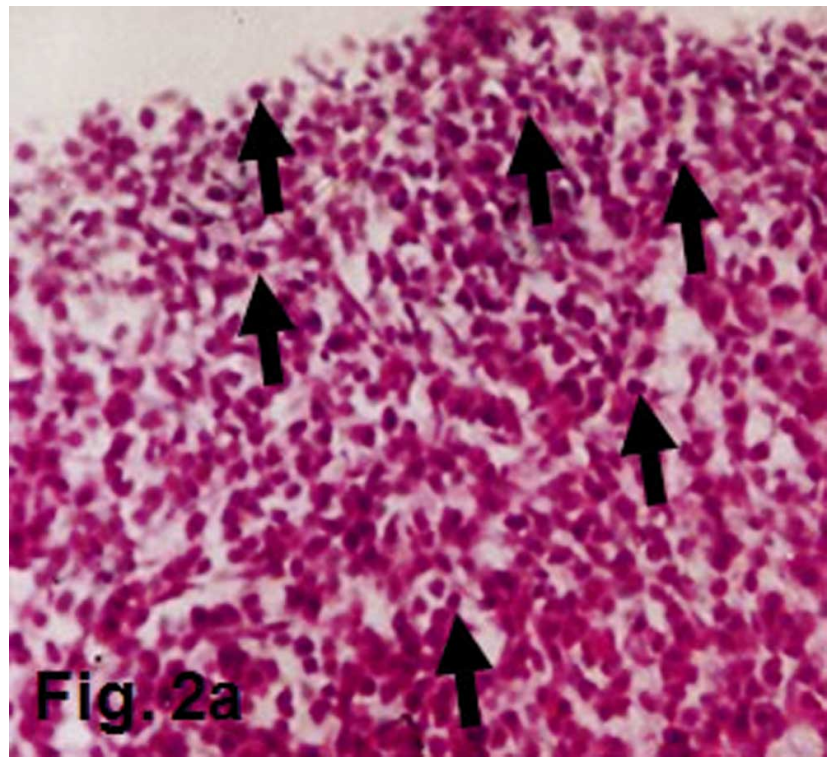

Fig. 2a. Spleen of control broiler showing lymphocytes (arrows) in the cortex of white pulp (H\&E, X 400).

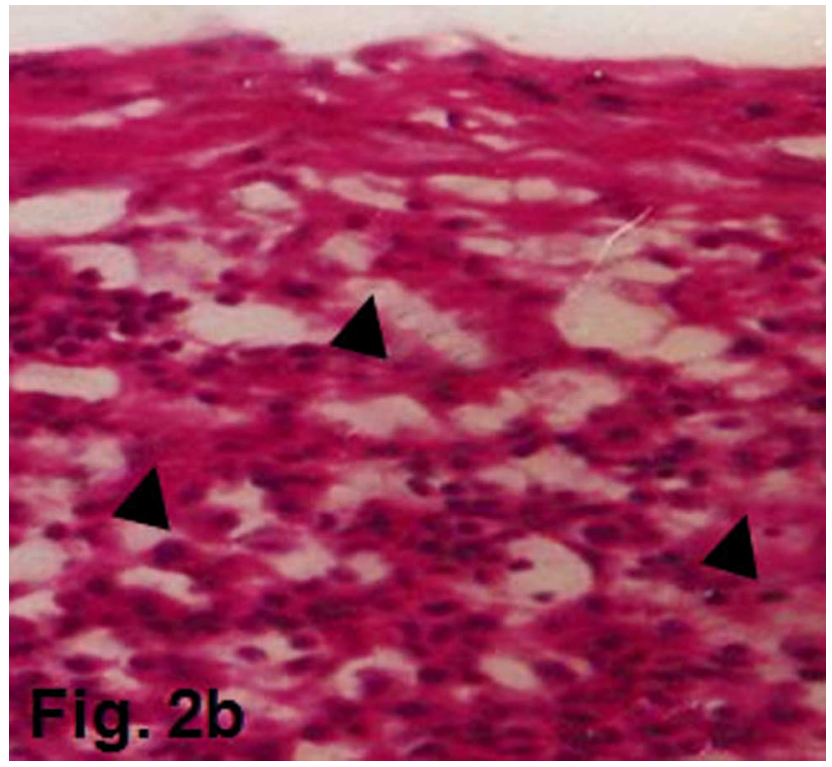

Fig. 2b. Spleen of Gumboro-infected broiler showing lymphocyte depleted areas (arrowhead) in the cortex of white pulp (H\&E, X 400). 


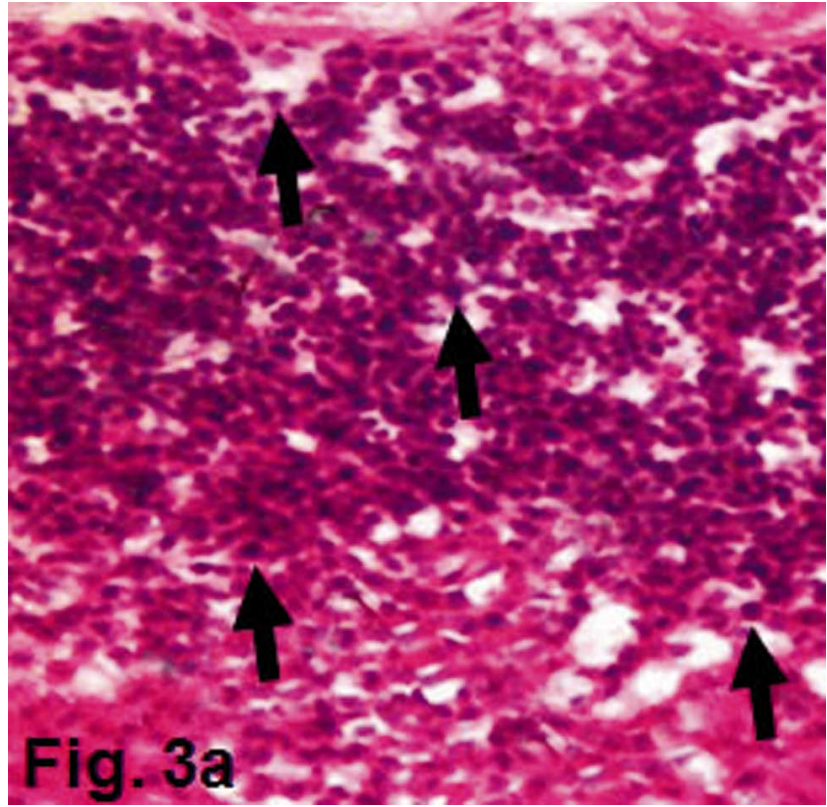

Fig. 3a. Thymus of control broiler showing lymphocytes (arrows) in the cortex (H\&E, X 400).

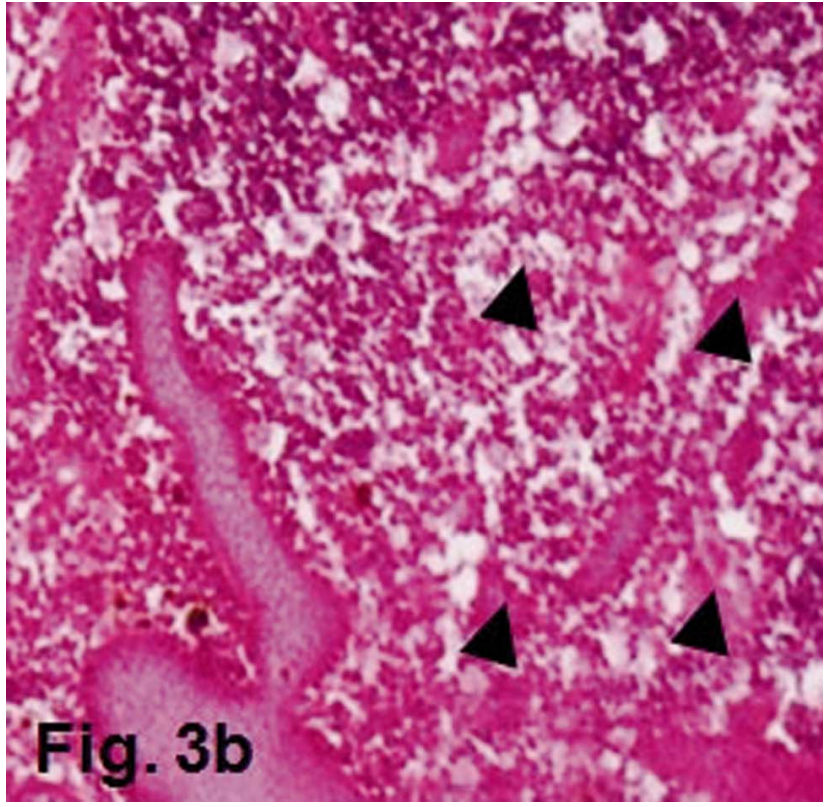

Fig. 3b. Thymus of Gumboro-infected broiler showing lymphocyte depleted areas (arrowhead) in the cortex (H\&E, X 400).

UDDIN, M. M.; ISLAM, M. S.; BASU, J. \& KHAN, M. Z. I. Distribución y cuantificación de linfocitos en los órganos linfoides principales de pollos de engorda infectados naturalmente con Gumboro. Int. J. Morphol., 30(4):1585-1589, 2012.

RESUMEN: La enfermedad de Gumboro es causada por el virus de la bursitis infecciosa (VBI), que destruye rápidamente los linfocitos B inmaduros de la bolsa de Fabricio, y causa supresión inmune y la elevada mortalidad en las granjas comerciales de pollos de engorde en Bangladesh. Para investigar el posible efecto del VBI en los linfocitos y su distribución en los órganos linfoides principales, la bolsa de Fabricio, incluyendo el bazo y el timo de pollos de engorde naturalmente infectados con Gumboro, se realizó una investigación en el Departamento de Anatomía e Histología, y el Departamento de Patología, Universidad Agrícola de Bangladesh, Bangladesh. Tanto la bolsa de Fabricio, bazo y el timo de pollos de engorde con 21 días de edad infectados con Gumboro y no infectados de la misma edad (control) se procesaron de forma rutinaria y se tiñeron con H \& E para examinar la distribución de los linfocitos en los órganos linfáticos principales, así cuantificar el número de linfocitos bajo campo de alta magnificación y compararlos con los de control. El número de linfocitos en la bolsa de Fabricio, bazo y timo de pollos infectados con Gumboro fue 27,20 $\pm 1,53,66,50 \pm 2,70$ y 79,30 \pm 3,92 , respectivamente, mientras que en los controles no infectados fue $121 \pm 3,82,89,90 \pm 2,09$ y $106,30 \pm 4,07$ respectivamente. El número de linfocitos fue significativamente $(p<0,05)$ más bajo en todos los órganos linfáticos de pollos de engorde infectados con Gumboro que los no infectados. La disminuición significativa de linfocitos en el bazo y timo, sugiere que el VBI no sólo destruye linfocitos en la bolsa de Fabricio, sino también en el bazo y el timo y, por tanto, puede suprimir severamente la respuesta inmune de pollos de engorde afectados por VBI.

PALABRAS CLAVE: Linfocitos; Enfermedad de Gumboro; Órganos linfoides; Pollos de engorde.

\section{REFERENCES}

Anderson, W. I.; Reid, W. M.; Lukert, P. D. \& Fletocher, O. J. Influence of infectious bursal disease on the development of immunity to Eimeria tenella. Avian Dis., 21(4):637-41, 1977.

Chen, L.; Ran, M. J; Shan, X. X.; Cao, M. P.; Yang, X. M. \&. Zhang, S. Q. BAFF enhances B-cell-mediated immune response and vaccine-protection against a very virulent IBDV in chickens. Vaccine, 27(9):1393-9, 2009.
Chowdhury, E. H.; Islam, M. R.; Das, P. M.; Dewan, M. L \& Khan, M. S. R. Acute infectious bursal disease in chicken: Pathological observation and virus isolation. Asian Aust. J. Anim. Sci., 9(4):465-9, 1996.

Elankumaran, S.; Heckert, R. A. \& Mours, L. Persistence and tissue distribution of a variant strain of infectious bursal disease virus in commercial broiler chickens. Proceeding of the II 
International Symposium on Infectious Bursal Disease and Chicken Infectious Anaemia, Rouischholzhausen, Germany, 2001. pp.353-65.

Giambrone, J. J.; Eidson C. S. \&. Kleven, S. H. Effect of infectious bursal disease on the response of chickens of chickens to Mycoplasma synoviae, Newcastle disease virus and infectious bronchitis virus. Am. J. Vet. Res., 36(2):251-3, 1977.

Gridley, M. F. Manual of histologic and special staining technique. $2^{\text {nd }}$ Ed. New York, MacGraw-Hill Book Company, 1960. pp.2532.

Hoque, M. M.; Omar, A. R.; Chong, L. K.; Hair-Bejo, M. \& Aini, I. Pathogenicity of Sspl-positive infectious bursal virus and molecular characterization of the VP2 hypervariable region. Avian Pathol., 30(4):369-80, 2001.

Islam, M. R.; Chowdhury, E. H.; Das, P. M \&. Dewan, M. L. Pathology of acute infectious bursal disease virus in chickens induced experimentally with a very virulent isolate. Indian $J$. Anim. Sci., 67:7-9, 1997.

Khan, M. Z. \& Hashimoto, Y. Large granular lymphocytes in the oviduct of developing and hormone treated chickens. Br. Poult. Sci., 42(2):180-3, 2001.

Khatri, M. \& Sharma, J. M. Response of embryonioc chicken lymphoid cells to infectious bursal disease virus. Vet. Immunol. Immunopathol., 127(3-4):316-24, 2009.

Okoye, J. O. \& Uzoukwu, M. Histopathogenesis of a local Nigerian isolate of infectious bursal disease virus in broilers. Proceeding of the II International Symposium on Infectious bursal Disease and Chicken Infectious Anaemia, Rouishchholzhausen, Germany, 2001. pp.365-83.

Rautenschlein, S.; Yeh, H. Y. \&. Sharma, J. M. A comparison of the immunopathogenesis of different IBDV strains. Proceeding of the II International Symposium on Infectious Bursal Disease and Chicken Infectious Anaemia, Rouischholzhausen, Germany, 2001. pp.311-23.

Sharma, J. M.; Dohms, J. E \& Metz, A. L. Comparative pathogenesis of serotype I and variant seritype II isolated of infectious bursal disease virus and their effects on humoral and cellular immune competence of specific pathogen free chickens. Avian Dis., 33(1):112-24, 1984.

Tanimura, N.; Tsukamoto, K.; Nakamura, M.; Narita, M. \& Yuasa, N. Pathological changes in specific-pathogen free chickens experimentally inoculated with European and Japanese highly virulent strains of infectious bursal disease virus. International Symposium on Infectious Bursal Diseases and Chicken Infectious Anaemia, Rouishholzhausen, Germany, 1994. pp.143-54.

Uddin, M. M.; Khan, M. Z. I.; Islam, K. N.; Kibria, A. S. M. G.; Adhikary, G. N.; Parvez, M. N. H.; Basu, J.; Uddin, M. B. \&
Rahman, M. M. Distribution of lymphocytes in the mucosa associated lymphoid tissues (MALT) of naturally occurring infectious bursal disease (IBD) in chicken. Pak. Vet. J., 30(2):67-71, 2010.

Wyeth, P. J. Effect of infectious bursal disease on the response of chickens to $S$. typhimurium and E. coli infections. Vet. Rec., 96(11):238-43, 1975.

Correspondence to:

Mohammad Mejbah Uddin

Associate Professor

Department of Anatomy and Histology

Faculty of Veterinary Medicine

Chittagong Veterinary and Animal Sciences University

Khulshi, Chittagong-4202

BANGLADESH

Doctoral Student, Laboratory of Clinical Pathology

Department of Veterinary Clinical Sciences

Faculty of Agriculture

Kagoshima University

Kagoshima 890-0065

JAPAN

Phone: +81-80-42720306

Email:mmu_cvasu@yahoo.com

Received: 09-01-2012

Accepted: 11-07-2012 